Article

\title{
Alum as a Catalyst for the Synthesis of Bispyrazole Derivatives
}

\author{
Mohammad Ali Zolfigol ${ }^{1, *}$, Ardeshir Khazaei ${ }^{1}$, Fatemeh Karimitabar ${ }^{1}$ and Masoud Hamidi ${ }^{2}$ \\ Received: 13 November 2015; Accepted: 29 December 2015; Published: 19 January 2016 \\ Academic Editor: Rajender S. Varma \\ 1 Faculty of Chemistry, Bu-Ali Sina University, Hamedan 6517838683, Iran; khazaei@basu.ac.ir (A.K.); \\ f.karimitabar@basu.ac.ir (F.K.) \\ 2 Medical Biotechnology Research Center, Guilan University of Medical Sciences, Rasht 4477166595, Iran; \\ hamidi_m@gums.ac.ir \\ * Correspondence: zolfi@basu.ac.ir; Tel.: +98-81-3828-2807
}

\begin{abstract}
Compounds with pyrazolemoieties as nitrogen-containing heterocyclic systems have received attention owing to their diverse biological activities. Alum $\left(\mathrm{KAl}\left(\mathrm{SO}_{4}\right)_{2} \cdot 12 \mathrm{H}_{2} \mathrm{O}\right)$ is an inexpensive, reusable and nontoxic catalyst used to synthesize $1 \mathrm{H}$-pyrazole derivatives via the reaction of 3-methyl-1-phenyl-1H-pyrazol-5(4H)-one and carbonyl compound under solvent-free conditions at $60{ }^{\circ} \mathrm{C}$. The proposed method has been used for the preparation of $1 H$-pyrazole derivatives to yield green products for cleaning-in-place and to avoid toxic catalysts and hazardous solvents in accordance with the philosophy of sustainable chemistry.
\end{abstract}

Keywords: Alum; bispyrazole derivatives; 3-methyl-1-phenyl-1H-pyrazol-5(4H)-one; Carbonyl compound; Solvent-free conditions

\section{Introduction}

The expanding focus on sustainable development strategies using economically straightforward and environmentally safe methods is apparent in the growth of sustainable chemistry. Sustainable, or green, chemistry offers the potential of decreasing by-products, waste, and energy costs using benign methods that employ alternative reaction media to replace volatile and hazardous solvents commonly used in organic methodologies [1,2]. Nowadays, solvent-free and solvent-less organic reactions occupy an important place in the realm of green chemistry. They offer many advantages, such as increased yield, easier workup, separation and purification, mild reaction conditions, decreased waste and benefits to industry and the environment [1,3]. Catalysis aids are green chemical processes that decrease undesirable environmental effects and the costs of these processes. Alum $\left(\mathrm{KAl}\left(\mathrm{SO}_{4}\right)_{2} \cdot 12 \mathrm{H}_{2} \mathrm{O}\right)$ has been widely used in organic methodology. This study introduces the term "dreamland catalyst" to denote a heterogeneous catalyst which is mild, efficient, safe, stable, low-cost, non-toxic, reliable, incorruptible, recyclable and easy to use [4]. The efficiency of alum has been reported for the synthesis of 1,4-dihydropyridines [5], cis-isoquinolic acids [6], mono- and disubstituted 2,3-dihydroquinazolin-4(1H)-ones [7], dihydropyrimidine using the Biginelli reaction [8], coumarins [9], 5-arylidene-2,4-thiazolidinedione [10], dibenzoxanthenes [7], 1,5-benzodiazepines [11], trisubstitutedimidazoles [5] and 4-substituted coumarins using the Pechmann reaction [9]. Synthesis of nitrogen-containing heterocyclic compounds has great value in natural and synthetic organic chemistry due to their therapeutic and pharmacological properties [2]. Compounds with pyrazolemoieties as nitrogen-containing heterocyclic systems have received attention owing to their diverse biological activities. These include anti-inflammatory, antipyretic and analgesic activities, uses as bactericides and fungicides, and promising inhibitory activity against monoamine oxidase for the treatment of Parkinson's and Alzheimer's 
diseases [1,4,12-14]. More specifically, 4,4'-(arylmethylene)bis(3-methyl-1-phenyl-1H-pyrazol-5-ol)s is an important class of pyrazolones used as anti-inflammatories [15], antipyretics, gastric secretion stimulatories [16], antidepressants [17], and antibacterial and anti-filaria agents [11,18-20]. These compounds have been also useful as fungicides, pesticides, dyestuffs [19] and as chelating and extracting reagents for metal ions [21]. Alum is an efficient and ecofriendly catalyst in organic transformations [3]; however, no studies have described the use of alum as a catalyst for the synthesis of $4,4^{\prime}$-(arylmethylene)bis(3-methyl-1-phenyl-1H-pyrazol-5-ol)s and 1-alkyl-3,3"-bis(5-hydroxy-3-methyl-1-phenyl-1H-pyrazol-4-yl)indolin-2-ones.

The significant role of compounds with pyrazole moieties in medicinal chemistry and interest in the use of heterogeneous catalysts has encouraged the use of alum for organic synthesis. This study reports on the preparation of a range of bispyrazole derivatives by means of the reaction of two equivalent 3-methyl-1-phenyl-1H-pyrazol-5(4H)-one compounds with one equivalent carbonyl compound.

\section{Experimental Section}

\subsection{Chemicals}

All chemicals were purchased from Merck or Fluka Chemical (Darmstadt, Germany). The known products were identified by comparison of their melting points and spectral data with those reported in the literature.

\subsection{General Procedure for Preparation of Bispyrazol Derivatives}

A mixture of $1 \mathrm{mmol}$ substituted aryl aldehyde or $\mathrm{N}$-alkyl substituted isatin derivative, $2 \mathrm{mmol}$ 3-methyl-1-phenyl-1H-pyrazol-5(4H)-one $(350 \mathrm{mg})$ and $0.1 \mathrm{~g} \mathrm{KAl}\left(\mathrm{SO}_{4}\right)_{2} \cdot 12 \mathrm{H}_{2} \mathrm{O}(20 \mathrm{~mol} \%)$ was stirred at $60^{\circ} \mathrm{C}$. After completion of the reaction as indicated by thin-layer chromatography (TLC) (Merck, Darmstadt, Germany), the reaction mixture was poured into water and stirred for $5 \mathrm{~min}$. The products were collected by filtration, washed with water, and then recrystallized using ethanol (EtOH) to provide the desired products.

\subsection{General Procedure for Catalyst Recovery}

To recover the catalyst, the reaction mixture was poured into water, the products were filtered and then the water was removed under vacuum. The catalyst was then washed with acetone and dried at room temperature.

\subsection{Physical Properties of Compounds 1a-e}

\subsubsection{3,3-Bis(5-hydroxy-3-methyl-1-phenyl-1H-pyrazol-4-yl)indolin-2-one (1a, Table 1)}

White solid; $\mathrm{mp} 174-176^{\circ} \mathrm{C}$; IR $\left(\mathrm{KBr}, \mathrm{cm}^{-1}\right): v=3413.12,3180.35,1714.35,1619.62,1595.91,1472$, 754.76, 691.09, 588.38.

${ }^{1} \mathrm{H}-\mathrm{NMR}\left(400 \mathrm{MHz}, \mathrm{DMSO}-d_{6}\right)$ : $\delta$ ppm $1.98\left(\mathrm{~s}, 6 \mathrm{H}, 2 \mathrm{CH}_{3}\right), 4.9(\mathrm{~s}, 2 \mathrm{H}, 2 \mathrm{OH}), 7.01(\mathrm{~s}, 1 \mathrm{H}, \mathrm{NH}), 7.22-7.24$ (m, 3H, Ar-H), 7.42 (br s, 10H, Ar-H), 7.67-7.96 (d, J = 6.9 Hz, 1H, Ar-H). ${ }^{13} \mathrm{C}-\mathrm{NMR}(400 \mathrm{MHz}$, DMSO- $\left.d_{6}\right)$ : $\delta$ ppm $43.50,110.36,118.94,121.90,124.87,126.45,127.52,128.75,129.19,129.36,142.07$, $142.62,147.73,160.94$.

\subsubsection{1-Benzyl-3,3-bis(5-hydroxy-3-methyl-1-phenyl-1H-pyrazol-4-yl)indolin-2-one (1b, Table 1)}

White solid; $\mathrm{mp} 205-207^{\circ} \mathrm{C}$; IR $\left(\mathrm{KBr}, \mathrm{cm}^{-1}\right): v=3412.37,3057.53,1715.15,1614.24,1498.76$, 1362.36, 1309.13, 1114.66, 838.64.

${ }^{1} \mathrm{H}-\mathrm{NMR}\left(400 \mathrm{MHz}\right.$, DMSO- $\left.d_{6}\right): \delta \mathrm{ppm} 1.98\left(\mathrm{~s}, 6 \mathrm{H}, 2 \mathrm{CH}_{3}\right), 4.96\left(\mathrm{~s}, 2 \mathrm{H}, \mathrm{CH}_{2} \mathrm{~N}\right), 6.85(\mathrm{br} \mathrm{s}, 2 \mathrm{H}, 2 \mathrm{OH})$, 7.22 (br s, 8H, Ar-H), 7.42 (br s, 7H, Ar-H), 7.67-7.89 (d, J = 6 Hz, 4H, Ar-H). ${ }^{13} \mathrm{C}-\mathrm{NMR}(400 \mathrm{MHz}$, 
DMSO-d 6 ): $\delta$ ppm 14.39, 17.39, 43.78, 98.27, 109.66, 118.78, 119.73, 120.711, 121.84, 122.56, 125.38, 126.45, $127.71,128.41,129.26,129.37,131.94,136.59,137.94,142.06,142.62,147.72$.

Table 1. The preparation of 1-alkyl-3,3-bis(5-hydroxy-3-methyl-1-phenyl-1H-pyrazol-4-yl)indolin-2-ones using alumas catalyst at $60^{\circ} \mathrm{C}$ under solvent free condition.

\begin{tabular}{|c|c|c|c|c|}
\hline Entry & Compound & Structure & Time (min) & Yield $^{a}(\%)$ \\
\hline 1 & $1 \mathrm{a}$ & & 20 & 92 \\
\hline 2 & $1 b$ & & 25 & 90 \\
\hline 3 & $1 \mathrm{c}$ & & 20 & 90 \\
\hline 4 & $1 d$ & & 15 & 87 \\
\hline 5 & $1 \mathrm{e}$ & & 30 & 81 \\
\hline
\end{tabular}

${ }^{a}$ Yield of isolated product.

2.4.3. 3,3-Bis(5-hydroxy-3-methyl-1-phenyl-1H-pyrazol-4-yl)-1-(prop-2-ynyl)indolin-2-one (1c, Table 1)

White solid; $\mathrm{mp} 174-176{ }^{\circ} \mathrm{C}$; IR $\left(\mathrm{KBr}, \mathrm{cm}^{-1}\right): v=3374.49,3259.34,3057.53,2127.31,1720.39$, $1622.99,1485.82,1092.48,755.75,692.00$.

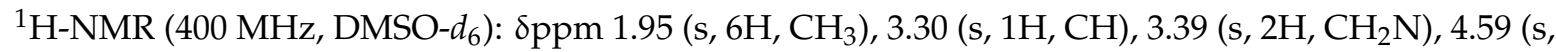
2H, OH), 7.18 (br s, 3H, Ar-H), 7.4 (br s, 10H, Ar-H), 7.65 (d, J = 6 Hz, 4H, Ar-H). ${ }^{13} \mathrm{C}-\mathrm{NMR}(400 \mathrm{MHz}$, DMSO- $d_{6}$ ): $\delta$ ppm 29.20, 75.13, 78.29, 108.68, 118.9, 122.89, 125.22, 128.48, 128.32, 131.94, 136.60, 137.88, $142.52,142.74,147.92,160.59$. 
2.4.4. 3,3-Bis(5-hydroxy-3-methyl-1-phenyl-1H-pyrazol-4-yl)-1-(3-(4-nitrophenoxy)propyl)indolin-2-one $(1 \mathrm{~d}$, Table 1)

Pale yellow solid; $\mathrm{mp} 146-148{ }^{\circ} \mathrm{C}$; $\mathrm{IR}\left(\mathrm{KBr}, \mathrm{cm}^{-1}\right): v=3366.50,3246.80,2935.01,2116.61,1727.30$, $1607.52,1509.21,1266.36,1111.54,844.04,752.06,690.72$.

${ }^{1} \mathrm{H}-\mathrm{NMR}\left(400 \mathrm{MHz}, \mathrm{DMSO}-d_{6}\right): \delta \mathrm{ppm} 1.98\left(\mathrm{~s}, 6 \mathrm{H}, 2 \mathrm{CH}_{3}\right), 2.10\left(\mathrm{~m}, 2 \mathrm{H}, \mathrm{CH}_{2}\right), 3.88-3.93(\mathrm{t}, J=6 \mathrm{~Hz}$, $\left.2 \mathrm{H}, \mathrm{CH}_{2} \mathrm{O}\right), 4.158-4.187\left(\mathrm{t}, J=6 \mathrm{~Hz}, 2 \mathrm{H}, \mathrm{CH}_{2} \mathrm{~N}\right), 5.11(\mathrm{~s}, 2 \mathrm{H}, 2 \mathrm{OH}), 7.05-7.11(5 \mathrm{H}, \mathrm{m}, \mathrm{Ar}-\mathrm{H}), 7.15-7.17$ (d, $J=8 \mathrm{~Hz}, 2 \mathrm{H}-\mathrm{Ar}), 7.39-7.44$ (m, 3H, Ar-H), 7.647(br s, 3H, Ar-H), 7.881-7.899 (d, J = 7.2 Hz,1H-Ar), 8.17-8.19 (d, $J=9.2 \mathrm{~Hz}, 2 \mathrm{H}-\mathrm{Ar}), 8.22-8.249$ (d, $J=9.2 \mathrm{~Hz}, 2 \mathrm{H}-\mathrm{Ar}) .{ }^{13} \mathrm{C}-\mathrm{NMR}\left(400 \mathrm{MHz}, \mathrm{DMSO}-d_{6}\right)$ : Sppm 26.91, 37.02, 64.43, 66.75, 79.30, 79.73, 109.94, 115.32, 115.38, 115.52, 123.26, 126.18, 126.29, 126.38, $128.09,129,31,133.80,141.23,144.39,144.791,162.66,164.17$.

2.4.5. 3,3-Bis(5-hydroxy-3-methyl-1-phenyl-1H-pyrazol-4-yl)-1-(3-(naphthalen-2-yloxy)propyl)indolin-2-one (1e, Table 1)

White solid; $\mathrm{mp} 160-162{ }^{\circ} \mathrm{C}$; IR $\left(\mathrm{KBr}, \mathrm{cm}^{-1}\right): v=3403.36,29779.31,1714,1621.25,1469.94,1098.78$, 921.65, 691.18, 595.78.

${ }^{1} \mathrm{H}-\mathrm{NMR}\left(400 \mathrm{MHz}, \mathrm{DMSO}-d_{6}\right)$ : $\delta$ ppm $1.73\left(\mathrm{~s}, 6 \mathrm{H}, 2 \mathrm{CH}_{3}\right), 1.94\left(\mathrm{~m}, 2 \mathrm{H}, \mathrm{CH}_{2}\right), 3.75(\mathrm{t}, J=6.4 \mathrm{~Hz}, 2 \mathrm{H}$, $\left.\mathrm{CH}_{2} \mathrm{O}\right), 3.95\left(\mathrm{t}, J=6.4 \mathrm{~Hz}, 2 \mathrm{H}, \mathrm{CH}_{2} \mathrm{~N}\right), 4.22(\mathrm{~s}, 2 \mathrm{H}, 2 \mathrm{OH}), 7.03(\mathrm{br} \mathrm{s}, 1 \mathrm{H}, \mathrm{Ar}-\mathrm{H}), 7.16-7.18(\mathrm{~d}, J=7.2 \mathrm{~Hz}, 3 \mathrm{H}$, Ar-H), 7.24-7.39(m, 10H, Ar-H), 7.62 (br s, 5H, Ar-H), 7.80-7.81(t, J = 7.2 Hz, 2H, ArH). ${ }^{13} \mathrm{C}-\mathrm{NMR}(400$ MHz, DMSO- $\left.d_{6}\right)$ : $\delta$ ppm 26.66, 37.05, 65.03, 67.65, 106.91, 108.89, 118.42, 118.77, 122.06, 123.57, 125.11, $126.37,126.71,127.55,128.51,128.77,128.97,129.28,134.28,141.23,144.39,144.79,156.47,162.66,166.32$.

\section{Results and Discussion}

This section reports on a simple, green, and efficient method for the condensation of aromatic aldehydes $(1.00 \mathrm{mmol})$ with 3-methyl-1-phenyl-1 $\mathrm{H}$-pyrazol-5(4H)-one $(2.00 \mathrm{mmol})$. It was exciting to note that all reactions proceeded rapidly with excellent yields (Figure 1).

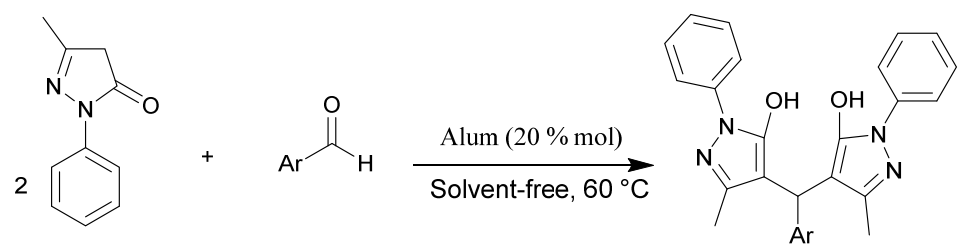

Figure 1. Synthesis of 4,4'-(arylmethylene)-bis(3-methyl-1-phenyl-1H-pyrazol-5-ol)s derivatives using Alum.

In a typical experiment, a solvent-free mixture of 3-methyl-1-phenyl-1H-pyrazol-5(4H)-one $(2.00 \mathrm{mmol})$ and 2-hydroxybenzaldehyde $(1.00 \mathrm{mmol})$ was heated at $60{ }^{\circ} \mathrm{C}$ in the presence of a catalytic amount of alum $(20 \% \mathrm{~mol})$.

The reaction was monitored by TLC. After completion of the reaction, the reaction mixture was poured into water and stirred for $5 \mathrm{~min}$. The solid product was collected by simple filtration and washed with water. The crude solid was then recrystallized using EtOH to provide pure products. Different solvents were used to estimate the effect of the solvent (Table 2). 
Table 2. $\mathrm{KAl}\left(\mathrm{SO}_{4}\right)_{2} \cdot 12 \mathrm{H}_{2} \mathrm{O}$ (alum)-catalyzed condensation of 3-methyl-1-phenyl-1H-pyrazol-5(4H)-one with aryl aldehyde under different reaction conditions ${ }^{\mathrm{a}}$.

\begin{tabular}{cccc}
\hline Entry & Solvent & Amount of Catalyst / mol \% & Yield $^{\mathbf{b}} \mathbf{( \% )}$ \\
\hline 1 & $\mathrm{H}_{2} \mathrm{O}$ & 20 & 78 \\
2 & $\mathrm{CH}_{3} \mathrm{CH}_{2} \mathrm{OH}$ & 20 & 79 \\
3 & $\mathrm{CH}_{3} \mathrm{CN}$ & 20 & 61 \\
4 & $\mathrm{DMF}$ & 20 & 78 \\
$5^{\mathrm{c}}$ & none & 20 & $95,92,89,85,81$ \\
6 & none & 25 & 95 \\
7 & none & 10 & 78 \\
8 & none & - & Trace
\end{tabular}

a The reaction were carried out in the presence 3-methyl-1-phenyl-1H-pyrazol-5(4H)-one (2 mmol), $1 \mathrm{mmol}$ of 2-hydroxybenzaldehyde and $\mathrm{KAl}\left(\mathrm{SO}_{4}\right)_{2} \cdot 12 \mathrm{H}_{2} \mathrm{O}$ at $60{ }^{\circ} \mathrm{C}$ for $60 \mathrm{~min}$ under solvent free condition; ${ }^{\mathrm{b}}$ Isolated yield; ${ }^{\mathrm{C}}$ Catalyst was reused for five times.

As shown, the reaction could be carried out in the absence of solvent to produce an excellent yield. To determine the best molar ratio of the catalyst, the reaction was tested for $10 \%, 20 \%$ and $25 \%$ mol. Table 1 indicates that $20 \%$ mol alum produced the best results in terms of reaction time and yield. No product was observed in the absence of catalyst (Table 2, entry 1) which further requires the use of alum in this transformation (Table 2, entry 8 ). The activity of the recycled alum was examined in 5 successive runs (Table 2, entry 5).

To evaluate the generality and versatility of this method, optimized conditions were employed and substituted aromatic aldehydes bearing either electron-donating or electron-withdrawing substituents with 3-methyl-1-phenyl-1H-pyrazol-5 $(4 H)$-one in the presence of alum to achieve the corresponding 4,4-(arylmethylene)-bis(3-methyl-1-phenyl-1H-pyrazol-5-ol)s. Table 3 indicates that the method is suitable and efficient for different aromatic aldehydes. The activation of the carbonyl compound by binding to alum with carbonyl oxygen enhanced the electrophilicity of the carbonyl carbon and improved the reaction rate.

Table 3. The preparation of 4,4'-(arylmethylene)-bis(3-methyl-1-phenylpyrazol-5-ol)s using alum as catalyst at $60^{\circ} \mathrm{C}$ under solvent-free conditions.

\begin{tabular}{|c|c|c|c|c|c|}
\hline Entry & Ar & Time (min) & Yield ${ }^{a}(\%)$ & mp. ${ }^{\circ} \mathrm{C}$ (lit.) & Reference \\
\hline 1 & $\mathrm{C}_{6} \mathrm{H}_{5}$ & 15 & 86 & 168-170 (169-171) & [13] \\
\hline 2 & $4-\mathrm{ClC}_{6} \mathrm{H}_{4}$ & 25 & 90 & $212-215(215-217)$ & {$[14]$} \\
\hline 3 & $2-\mathrm{OHC}_{6} \mathrm{H}_{4}$ & 20 & 95 & $226-228(222-226)$ & [13] \\
\hline 4 & $2-\mathrm{ClC}_{6} \mathrm{H}_{4}$ & 25 & 87 & $235-236(235-237)$ & {$[14]$} \\
\hline 5 & $2-\mathrm{MeOC}_{6} \mathrm{H}_{4}$ & 15 & 91 & $211-214(210-213)$ & [13] \\
\hline 6 & $4-\mathrm{NO}_{2} \mathrm{C}_{6} \mathrm{H}_{4}$ & 60 & 85 & $217-220(218-220)$ & [13] \\
\hline 7 & $3-\mathrm{NO}_{2} \mathrm{C}_{6} \mathrm{H}_{4}$ & 40 & 90 & $149-150(153-155)$ & [13] \\
\hline 8 & 2-Thienyl & 30 & 90 & $185-187$ (181-183) & [14] \\
\hline 9 & 2-Furyl & 40 & 88 & 187-190 (188-191) & [20] \\
\hline 10 & $4-\mathrm{MeC}_{6} \mathrm{H}_{4}$ & 25 & 85 & $201-203(202-204)$ & [14] \\
\hline 11 & $4-\mathrm{CNC}_{6} \mathrm{H}_{4}$ & 40 & 90 & $215-218(210-212)$ & [14] \\
\hline 12 & 2-Naphtyl & 15 & 92 & $201-203$ (204-206) & [20] \\
\hline 13 & $4-\mathrm{OHC}_{6} \mathrm{H}_{4}$ & 50 & 89 & $159-162(155-157)$ & [20] \\
\hline
\end{tabular}


Table 4. Comparison of the results on the synthesis of 4,4'-(arylmethylene)bis(3-methyl-1-phenyl-1Hpyrazol-5-ols) catalyzed by alum with those obtained by the other catalyst ${ }^{\mathrm{a}}$.

\begin{tabular}{cccc}
\hline Entry & Catalyst & Time (min) & Yield a $\mathbf{~}^{\mathbf{\%})}$ \\
\hline 1 & Alum & 20 & 95 \\
2 & Oxalic acid.dihydrate & 25 & 90 \\
3 & Silicasulfuric acid(sSA) & 60 & 82 \\
4 & $\mathrm{KHSO}_{4}$ & 60 & 81 \\
5 & $\mathrm{NaHSO}_{4} \mathrm{H}_{2} \mathrm{O}$ & 70 & 77 \\
6 & $\mathrm{Fe}\left(\mathrm{HSO}_{4}\right)_{3}$ & 78 \\
7 & $\mathrm{Al}\left(\mathrm{HSO}_{4}\right)_{3}$ & 105 & 82 \\
8 & $\mathrm{FeCl}_{3}$ & 50 & 85 \\
9 & $\mathrm{AlCl}_{3}$ & 110 & 85 \\
10 & $\mathrm{Citric} \mathrm{acid}$ & 75 & 76 \\
11 & $\mathrm{CuFe} \mathrm{O}_{4}$ & 25 & 89 \\
12 & $\mathrm{MgO}$ & 80 & 62 \\
13 & $\mathrm{ZnO}$ & 70 & 68 \\
14 & $\mathrm{Oxone}$ & 75 & 78 \\
\hline
\end{tabular}

${ }^{a}$ The reactions were carried out by the condensation of 3-methyl-1-phenyl-1H-pyrazol-5(4H)-one with 2-hydroxybenzaldehyde at $60^{\circ} \mathrm{C}$ under solvent free condition.

The efficiency of alum was compared with the results of other catalysts (Table 4) using a condensation of 3-methyl-1-phenyl-1H-pyrazol-5(4H)-one with 2-hydroxybenzaldehyde under the test conditions described above.

As Table 4 indicates, alum remarkably improved the synthesis of 4,4'-(arylmethylene)-bis (3-methyl-1-phenyl-1H-pyrazol-5-ol)s.

To compare the efficiency of our catalyst with the reported catalysts for the synthesis of 4,4'-(arylmethylene)-bis(3-methyl-1-phenyl-1H-pyrazol-5-ol)s, we have tabulated the results of these catalysts to perform the condensation of 3-methyl-1-phenyl-1H-pyrazol-5(4H)-one with 4-chlorobenzaldehyde, in Table 5. As Table 5 indicates, the reaction times were shorter and the yields were higher when our catalysts were utilized.

Table 5. Comparison of the results on the synthesis of $4,4^{\prime}$-((4-nitrophenyl)methylene)bis (3-methyl-1-phenyl-1H-pyrazol-5-ol)s catalyzed by alum with those obtainedby the recently reported catalysts ${ }^{\text {a }}$.

\begin{tabular}{|c|c|c|c|}
\hline Reaction Condition & Time (min) & Yield $^{b}(\%)$ & Reference \\
\hline $\begin{array}{l}\text { Silica-bonded S-sulfonic acid (sBSSA) }(0.20 \mathrm{~g}) \text {, } \\
\text { EtOH, reflux }\end{array}$ & 50 & 90 & [14] \\
\hline PEG-400, $110{ }^{\circ} \mathrm{C}$ & 150 & 90 & [22] \\
\hline$\left[\mathrm{P}_{4} \mathrm{VPy}-\mathrm{BuSO}_{3} \mathrm{H}\right] \mathrm{HSO}_{4}(0.1 \mathrm{mmol})$, Ethanol, reflux & 48 & 95 & [23] \\
\hline$[$ Sipmim $] \mathrm{HSO}_{4}(0.20 \mathrm{~g})$, Ethanol, reflux condition & 120 & 90 & [24] \\
\hline Alum $(20 \% \mathrm{~mol})$, Solvent-free, $60^{\circ} \mathrm{C}$ & 25 & 90 & $-c$ \\
\hline
\end{tabular}

a The reactions were carried out by the condensation of 3-methyl-1-phenyl-1H-pyrazol-5(4H)-one with 4-chlorobenzaldehyde; ${ }^{b}$ Isolated yield; ${ }^{c}$ Our work.

Isatins are starting materials used for drug synthesis and have shown a wide range of biological effects. To further expand the scope of the reaction in the present study [25], the aromatic aldehydes were replaced with $\mathrm{N}$-alkyl isatin derivatives (Figure 2). 

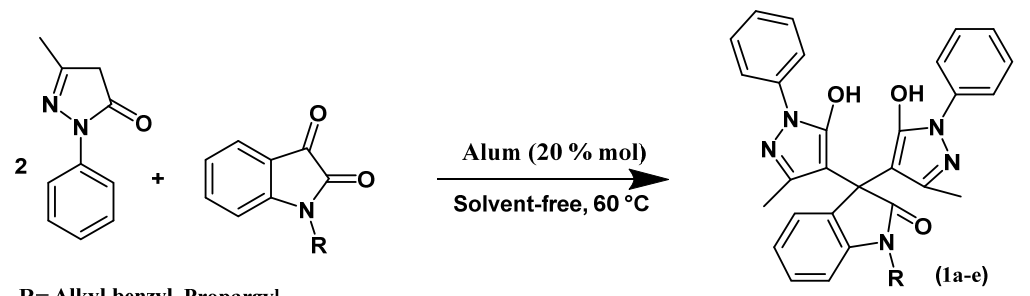

Figure 2. Synthesis of 1-alkyl-3,3'-bis(5-hydroxy-3-methyl-1-phenyl-1H-pyrazol-4-yl)indolin-2-one derivatives using Alum.

The first step was preparation of the prerequisite $N$-alkyl isatin derivatives. Perillo et al. [26] undertook a comprehensive reinvestigation of this protocol and examined a range of bases $\left(\mathrm{Na}_{2} \mathrm{CO}_{3}\right.$, $\mathrm{K}_{2} \mathrm{CO}_{3}, \mathrm{Cs}_{2} \mathrm{CO}_{3}, \mathrm{CaH}_{2}, \mathrm{TEA}, \mathrm{LiOH}, \mathrm{NMM}, \mathrm{NaOEt}$ ) in different solvents (DMF, DMA, HMPT, MeCN, DMSO, NMP) and found that optimal conditions consisted of $\mathrm{K}_{2} \mathrm{CO}_{3}$ or $\mathrm{Cs}_{2} \mathrm{CO}_{3}$ and a few drops of DMF or N-methyl-2-pyrrolidinone (Figure 3).<smiles>O=C1Nc2ccccc2C1=O</smiles>

R= Alkyl,benzyl, Propargyl

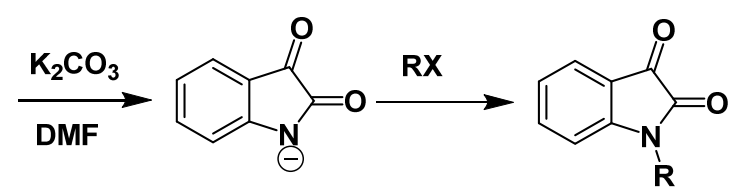

(2a-d)

Figure 3. Synthetic route for $N$-substituted isatins $2 \mathrm{a}-\mathrm{d}$.

Using this method, the reactions of 2a-d with alkyl halides and isatin produced the corresponding $\mathrm{N}$-alkyl substituted isatin derivatives (Table 6).

Table 6. N-Substituted isatins 2a-d.

\begin{tabular}{cc}
\hline Compound & $\mathbf{R}$ \\
\hline $2 \mathrm{a}$ & $\mathrm{CH}_{2} \mathrm{C} \equiv \mathrm{CH}$ \\
$2 \mathrm{~b}$ & $\mathrm{CH}_{2} \mathrm{Ph}$ \\
$2 \mathrm{c}$ & $4-\mathrm{NO}_{2} \mathrm{C}_{6} \mathrm{H}_{4} \mathrm{OCH}_{2} \mathrm{CH}_{2} \mathrm{CH}_{2}$ \\
$2 \mathrm{~d}$ & $\mathrm{C}_{10} \mathrm{H}_{7}-2 \mathrm{OCH}_{2} \mathrm{CH}_{2} \mathrm{CH}_{2}$ \\
\hline
\end{tabular}

Under these optimal conditions, the scope and generality of the protocol was next examined by employing $N$-alkyl substituted isatins derivatives $(1 \mathrm{mmol})$ and 3-methyl-1-phenyl-1H-pyrazol-5(4H)-one (2 mmol).

As seen in Table $1, N$-alkyl isatin derivatives easily transformed into the desired products with good yields. All products were fully characterized and their structures were confirmed by $\mathrm{IR}^{1}{ }^{1} \mathrm{H}$ and ${ }^{13} \mathrm{C}-\mathrm{NMR}$ spectra.

\section{Conclusions}

A solvent-free reaction is favored in sustainable chemistry. Alum, as a dreamland and green catalyst, offers a simple, nontoxic and inexpensive method for the synthesis of 4,4'-(arylmethylene)bis(3-methyl-1-phenyl-1H-pyrazol-5-ol)s and 1-alkyl-3,3'-bis(5-hydroxy-3-methyl-1-phenyl-1H-pyrazol-4yl)indolin-2-ones. The procedure is simple, cost-effective, clean, and mild. The reaction products show generality with high yield using a simple experimental and workup procedure, making it an appropriate process that is compatible with green chemistry disciplines. 
Acknowledgments: The authors acknowledge the Bu-Ali Sina University Research Council and Center of Excellence in Development of Environmentally Friendly Methods for Chemical Synthesis (CEDEFMCS) for providing support to this work.

Author Contributions: Mohammad Ali Zolfigol and Ardeshir Khazaei conceived, designed, and analyzed the experiments. Fatemeh Karimitabar conceived, designed, performed and analyzed the experiments. Fatemeh Karimitabar and Masoud Hamidi contributed substantially to the writing and revising of the manuscript.

Conflicts of Interest: The authors declare no conflict of interest.

\section{References}

1. Longhi, K.; Moreira, D.N.; Marzari, M.R.B.; Floss, V.M.; Bonacorso, H.G.; Zanatta, N.; Martins, M.A.P. An efficient solvent-free synthesis of NH-pyrazoles from $\beta$-dimethylaminovinylketones and hydrazine on grinding. Tetrahedron Lett. 2010, 51, 3193-3196. [CrossRef]

2. Sachdeva, H.; Dwivedi, D.; Saroj, R. Alum catalyzed simple, efficient, and green synthesis of 2-[3-amino-5-methyl-5-(pyridin-3-yl)-1,5-dihydro-4H-1,2,4-triazol-4-yl] propanoic acid derivatives in aqueous media. Sci. World J. 2013, 2013. [CrossRef] [PubMed]

3. Sonar, S.S.; Shelke, K.F.; Kakade, G.K.; Shingate, B.B.; Shingare, M.S. Alum: An efficient catalyst for one-pot synthesis of $\alpha$-aminophosphonates. Chin. Chem. Lett. 2009, 20, 1042-1046. [CrossRef]

4. Zare, A.; Merajoddin, M.; Abi, F.; Moosavi-Zare, A.R.; Mokhlesi, M.; Zolfigol, M.A.; Asgari, Z.; Khakyzadeh, V.; Hasaninejad, A.; Khalafi-Nezhad, A. Trityl chloride (TrCl): Efficient and homogeneous organocatalyst for the solvent-free synthesis of 14-aryl-14H-dibenzo $[a, j]$ xanthenes by in situ formation of carbocationic system. J. Chin. Chem. Soc. 2012, 59, 860-865. [CrossRef]

5. Mohammadi, A.A.; Mivechi, M.; Kefayati, H. Potassium aluminum sulfate (alum): An efficient catalyst for the one-pot synthesis of trisubstituted imidazoles. Monatsh. Chem. Chem. Mon. 2008, 139, 935-937. [CrossRef]

6. Azizian, J.; Mohammadi, A.A.; Karimi, A.R.; Mohammadizadeh, M.R. A stereoselective three-component reaction: $\mathrm{KAl}\left(\mathrm{SO}_{4}\right)_{2} \cdot 12 \mathrm{H}_{2} \mathrm{O}$, an efficient and reusable catalyst for the one-pot synthesis of cis-isoquinolonic acids. J. Org. Chem. 2005, 70, 350-352. [CrossRef] [PubMed]

7. Dabiri, M.; Baghbanzadeh, M.; Nikcheh, M.S.; Arzroomchilar, E. Eco-friendly and efficient one-pot synthesis of alkyl-or aryl-14H-dibenzo $[a, j]$ xanthenes in water. Bioorg. Med. Chem. Lett. 2008, 18, 436-438. [CrossRef] [PubMed]

8. Azizian, J.; Mohammadi, A.A.; Karimi, A.R.; Mohammadizadeh, M.R. $\mathrm{KAl}\left(\mathrm{SO}_{4}\right)_{2} \cdot 12 \mathrm{H}_{2} \mathrm{O}$ supported on silica gel as a novel heterogeneous system catalyzed biginelli reaction: One-pot synthesis of di-hydropyrimidinones under solvent-free conditions. Appl. Catal. A Gen. 2006, 300, 85-88. [CrossRef]

9. Azizian, J.; Mohammadi, A.A.; Bidar, I.; Mirzaei, P. $\mathrm{KAl}\left(\mathrm{SO}_{4}\right)_{2} \cdot 12 \mathrm{H}_{2} \mathrm{O}$ (alum) a reusable catalyst for the synthesis of some 4-substituted coumarins via pechmann reaction under solvent-free conditions. Monatsh. Chem. Chem. Mon. 2008, 139, 805-808. [CrossRef]

10. Shelke, K.F.; Sapkal, S.B.; Kakade, G.K.; Sadaphal, S.A.; Shingate, B.B.; Shingare, M.S. Alum catalyzed simple and efficient synthesis of 5-arylidene-2,4-thiazolidinedione in aqueous media. Green Chem. Lett. Rev. 2010, 3, 17-21. [CrossRef]

11. Mahajan, R.N.; Havaldar, F.H.; Fernandes, P.S. Syntheses and biological activity of heterocycles derived from 3-methoxy-1-phenyl-1H-pyrazole-5-carboxylate. J. Indian Chem. Soc. 1991, 68, 245-246.

12. Selvam, C.; Jachak, S.M.; Thilagavathi, R.; Chakraborti, A.K. Design, synthesis, biological evaluation and molecular docking of curcumin analogues as antioxidant, cyclooxygenase inhibitory and anti-inflammatory agents. Bioorg. Med. Chem. Lett. 2005, 15, 1793-1797. [CrossRef] [PubMed]

13. Zang, H.; Su, Q.; Mo, Y.; Cheng, B. Ionic liquid under ultrasonic irradiation towards a facile synthesis of pyrazolone derivatives. Ultrason. Sonochem. 2011, 18, 68-72. [CrossRef] [PubMed]

14. Niknam, K.; Saberi, D.; Sadegheyan, M.; Deris, A. Silica-bonded s-sulfonic acid: An efficient and recyclable solid acid catalyst for the synthesis of 4,4'-(arylmethylene)bis(1H-pyrazol-5-ols). Tetrahedron Lett. 2010, 51, 692-694. [CrossRef]

15. Sugiura, S.; Ohno, S.; Ohtani, O.; Izumi, K.; Kitamikado, T.; Asai, H.; Kato, K.; Hori, M.; Fujimura, H. Syntheses and antiinflammatory and hypnotic activity of 5-alkoxy-3-(N-substituted carbamoyl)-1-phenylpyrazoles. J. Med. Chem. 1977, 20, 80-85. [CrossRef] [PubMed] 
16. Rosiere, C.E.; Grossman, M.I. An analog of histamine that stimulates gastric acid secretion without other actions of histamine. Science 1951, 113, 651. [CrossRef] [PubMed]

17. Bailey, D.M.; Hansen, P.E.; Hlavac, A.G.; Baizman, E.R.; Pearl, J.; DeFelice, A.F.; Feigenson, M.E. 3,4-diphenyl-1H-pyrazole-1-propanamine antidepressants. J. Med. Chem. 1985, 28, 256-260. [CrossRef] [PubMed]

18. Chauhan, P.M.S.; Singh, S.; Chatterjee, R.K. Antifilarial profiles of substituted pyrazoles: A new class of antifilarial agents. Indian J. Chem. Sect. B Org. Chem. 1993, 32, 858-861.

19. Londershausen, M. Review: Approaches to new parasiticides. Pestic. Sci. 1996, 48, 269-292. [CrossRef]

20. Karimi-Jaberi, Z.; Pooladian, B.; Moradi, M.; Ghasemi, E. 1,3,5-Tris(hydrogensulfato) benzene: A new and efficient catalyst for synthesis of 4,4'-(arylmethylene)bis(1H-pyrazol-5-ol) derivatives. Chin. J. Catal. 2012, 33, 1945-1949. [CrossRef]

21. Garnovskii, A.D.; Uraev, A.I.; Minkin, V.I. Metal complexes from aryl and hetarylazocompounds. Arkiv. 2004, 3, 29-41.

22. Hasaninejad, A.; Zare, A.; Shekouhy, M.; Golzar, N. Efficient synthesis of 4,4'-(arylmethylene)-bis (3-methyl-1-phenylpyrazol-5-ol) derivatives in PEG-400 under catalyst-free conditions. Org. Prep. Proced. Int. 2011, 43, 131-137. [CrossRef]

23. Boroujeni, K.P.; Shojaei, P. Poly (4-vinylpyridine)-supported dual acidic ionic liquid: An environmentally friendly heterogeneous catalyst for the one-pot synthesis of 4,4'-(arylmethylene)bis(3-methyl-1-phenyl-1H-pyrazol-5-ols). Turk. J. Chem. 2013, 37, 756-764. [CrossRef]

24. Baghernejad, M.; Niknam, K. Synthesis of 4,4'-(arylmethylene)bis(1H-pyrazol-5-ols) using silica-bonded ionic liquid as recyclable catalyst. Int. J. Chem. 2012, 4, 52. [CrossRef]

25. Da Silva, J.F.; Garden, S.J.; Pinto, A.C. The chemistry of isatins: A review from 1975 to 1999. J. Braz. Chem. Soc. 2001, 12, 273-324. [CrossRef]

26. Shmidt, M.S.; Reverdito, A.M.; Kremenchuzky, L.; Perillo, I.A.; Blanco, M.M. Simple and efficient microwave assisted $\mathrm{N}$-alkylation of isatin. Molecules 2008, 13, 831-840. [CrossRef] [PubMed]

(C) 2016 by the authors; licensee MDPI, Basel, Switzerland. This article is an open access article distributed under the terms and conditions of the Creative Commons by Attribution (CC-BY) license (http://creativecommons.org/licenses/by/4.0/). 